\title{
Activation/Inhibition of mast cells by supra-optimal antigen concentrations
}

Michael Huber

\begin{abstract}
Mast cells (MCs) are tissue resident cells of hemopoietic origin and are critically involved in allergic diseases. MCs bind lgE by means of their high-affinity receptor for lgE (FcعRI). The FcعRl belongs to a family of multi-chain immune recognition receptors and is activated by cross-linking in response to multivalent antigens (Ags)/allergens. Activation of the FcERI results in immediate release of preformed granular substances (e.g. histamine, heparin, and proteases), generation of arachidonic acid metabolites, and production of pro-inflammatory cytokines. The FceRl shows a remarkable, bell-shaped dose-response behavior with weak induction of effector responses at both low and high (so-called supra-optimal) Ag concentrations. This is significantly different from many other receptors, which reach a plateau phase in response to high ligand concentrations. To explain this unusual dose-response behavior of the FcERl, scientists in the past have drawn parallels to so-called precipitin curves resulting from titration of Ag against a fixed concentration of antibody (Ab) in solution (a.k.a. Heidelberger curves). Thus, for high, supra-optimal Ag concentrations one could assume that every lgE-bound FcERl formed a monovalent complex with "its own Ag", thus resulting in marginal induction of effector functions due to absence of receptor cross-linking. However, this was never proven to be the case. More recently, careful studies of FceRl activation and signaling events in MCs in response to supra-optimal Ag concentrations have suggested a molecular explanation for the descending part of this bell-shaped curve. It is obvious now that extensive FcعRl/IgE/Ag clusters are formed and inhibitory molecules and signalosomes are engaged in response to supra-optimal cross-linking (amongst them the Src family kinase Lyn and the inositol-5'-phosphatase SHIP1) and they actively down-regulate MC effector responses. Thus, the analysis of $M C$ signaling triggered by supra-optimal crosslinking holds great potential for identifying novel targets for pharmacologic therapeutic intervention to benefit patients with acute and chronic allergic diseases.
\end{abstract}

Keywords: Mast cell, Allergy, SHIP1, Lyn, PKC- $\delta$, High-affinity receptor for IgE, Dose-response behavior, Inhibitory signalosome

\section{Lay abstract}

Mast cells are central players in allergic diseases like hay fever and asthma. When allergens bind to specific receptors (called FceRI) on the surface of mast cells, various intracellular events are triggered, resulting in the secretion of inflammatory mediators, such as histamine and proteases. These mediators are responsible for the well known symptoms of allergies (e.g. itching, sneezing, and coughing). In principle, receptors for different ligands are expressed by every cell, enabling each cell to sense its environment and react to it in an appropriate

Correspondence: mhuber@ukaachen.de

Institute of Biochemistry and Molecular Immunology, University Clinic, RWTH Aachen University, Pauwelsstr. 30, Aachen 52074, Germany fashion. Usually, the concentration of the ligand correlates with the extent of the ligand-induced cellular response. Intriguingly, this is not the case for the FceRI. High, so-called supra-optimal allergen concentrations result in only weak activation of mast cells, whereas lower concentrations of allergen can cause strong activation. The reason is that high allergen concentrations engage inhibitory mechanisms, which do not allow for the induction of mediator secretion. In recent years, several intracellular proteins involved in such inhibitory mechanisms have been identified and their functional interactions are currently being elucidated. Thus, further investigation of this cell-intrinsic shut-off mechanism and identification of additional proteins involved should 
enable researchers to define novel molecular targets for pharmacologic intervention. The aim would be to exploit this knowledge to actively silence the mast cell during pollen season.

\section{Review}

\section{The cell and its receptor}

Mast cells (MCs) are hemopoietically derived tissue resident cells that are concentrated in tissues close to the external environment, i.e., the skin and mucosal membranes of the intestine and airways [1]. One of their main functions is to act as guards, alerting the body to invasion by bacteria, parasites and viruses and initiating an inflammatory response [2-5]. On the pathophysiological side, amongst others MCs have attained inglorious publicity as central effector cells in acute allergic disorders [6]. Here, MCs recognize multivalent allergens/ antigens (Ags) via IgE immunoglobulins, which are bound to high-affinity IgE receptors (FceRI) on the surface of the MCs. Ag-triggered activation of the FceRI then results in several pro-inflammatory responses, such as release of preformed mediators (e.g. histamine, proteoglycans, and proteases) from intracellular granules in a process called degranulation, and de-novo production and release of arachidonic acid metabolites (e.g. leukotrienes and prostaglandins) as well as cytokines and chemokines (e.g. IL-6, TNF-alpha and MCP-1) [7]. As a result, MCs play a central role in the development of type I hypersensitivity reactions $[8,9]$.

The FceRI on murine MCs and basophils consists of an $\alpha$-subunit, a $\beta$-subunit, and two disulfide-bridged $\gamma$ subunits $\left(\alpha \beta \gamma_{2}\right)$ [10] (Figure 1A). The $\alpha$-subunit, which contains only a short cytoplasmic tail of 17 amino acids, binds to the constant Ce3 region of the IgE molecule via

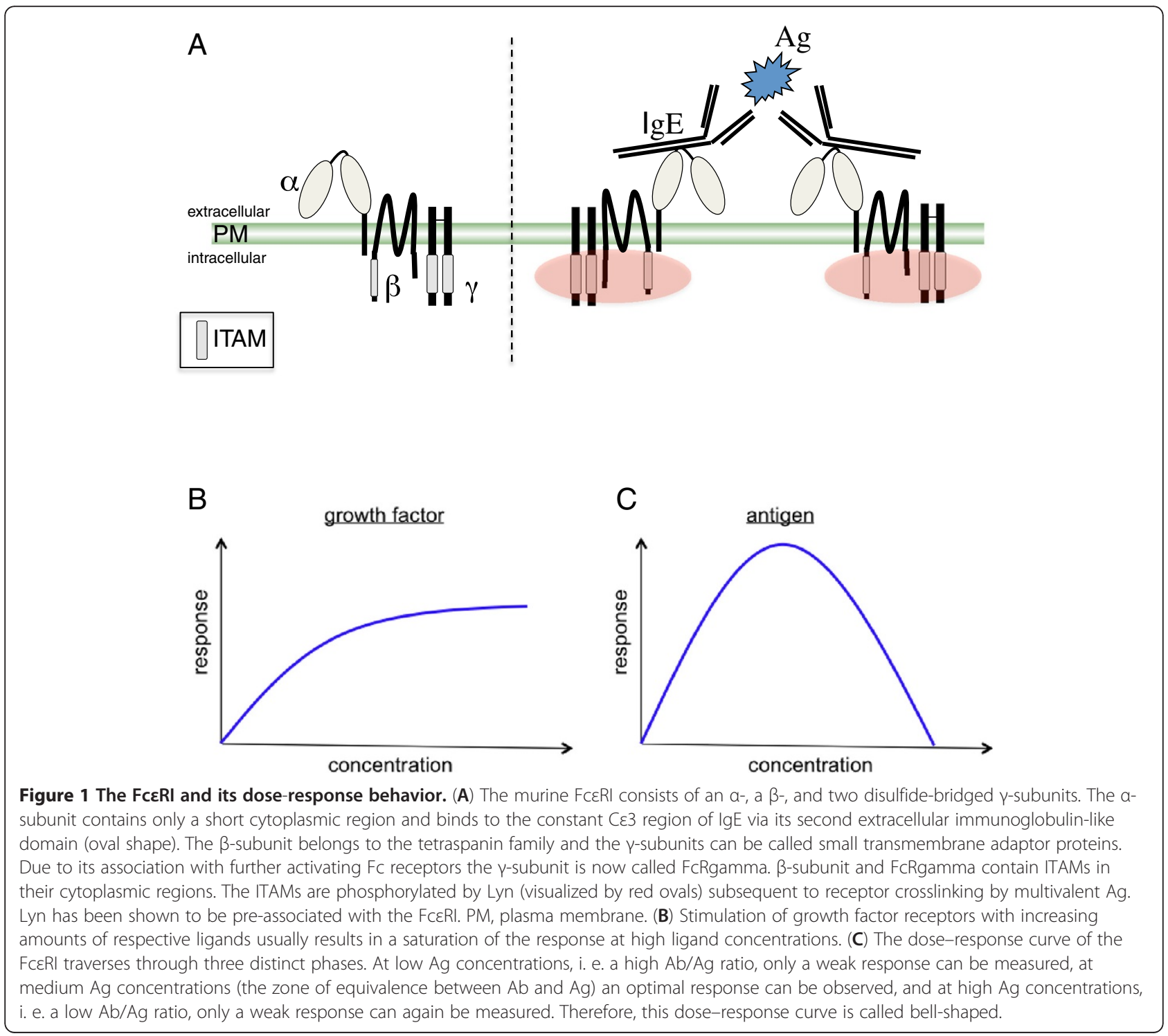


its second extracellular immunoglobulin-like do-main [11]. The $\beta$-subunit, a tetraspanin, and the $\gamma$-subunits contain immunoreceptor tyrosine-based activation motifs (ITAMs) in their cytoplasmic domains [12], which, when phosphorylated by the Src family kinase (SFK) Lyn after receptor crosslinking by multivalent Ag, trigger signaling events by attracting cytoplasmic proteins that contain phosphotyrosine-binding $\mathrm{SH} 2-$ domains [7]. Lyn has been shown to be pre-associated with the FceRI $[13,14]$. Of note, the $\gamma$-subunit of the FceRI also associates with other activating Fc receptors and therefore is now referred to as FcRgamma [15]. Though the IgE Fc-fragment is dimeric by nature, IgEinduced crosslinking of FceRIs does not occur in the absence of Ag. Interaction of IgE with the $\alpha$-subunit of one FceRI prohibits concomitant binding to a second FceRI $\alpha$-subunit [16]. Moreover, extensive glycosylation of the FceRI $\alpha$-subunit is thought to suppress spontaneous aggregation of the FceRI [7]. Thus, activation requires crosslinking of two or more IgE-bound receptors by multivalent Ag. However, binding of IgE to the FceRI is not a mere passive presensitization step to confer $\mathrm{Ag}$ specificity on the $\mathrm{MC}$, but rather it induces $\mathrm{Ag}$ independent signaling events that actively promote $\mathrm{MC}$ survival [17-19]. For completeness, it has to be added that whereas the FceRI on murine MCs always contains the $\beta$-chain [10], the FceRI can be expressed in two forms in human MCs and basophils, one containing the $\beta$-chain and one lacking the $\beta$-chain [11]. The $\beta$-chain-containing FceRI is also expressed on human eosinophils, whereas murine eosinophils do not express FceRI $[20,21]$. Moreover, the $\beta$-chain-lacking FceRI can also be found in human monocytes, Langerhans cells and dendritic cells $[22,23]$. The exclusive expression of the $\beta$-chain-containing FceRI in murine cells is because all three chains have to be present for cell surface expression [10]. In human cells, expression of the $\beta$-chain is dispensable for surface expression of the FceRI, however, the human $\beta$-chain has been shown by Kinet and colleagues to exert two important amplifier functions. Compared to a human FceRI that only consists of $\alpha$ chain and FcRgamma, the presence of the $\beta$-chain enhances both FceRI stability and surface expression as well as activation mechanisms $[24,25]$.

\section{Cross-link it - the precipitin way?}

Many receptors, like receptor tyrosine kinases and cytokine receptors, require ligand-mediated dimerization for their activation [26]. The dose-response behavior of such receptors differs significantly from that of the FceRI. These different dose-response curves are sketched in Figure 1. Whereas increasing concentrations of growth factors result in a saturated response (e.g. production of cytokines or upregulation of cell surface molecules), the Ag dose-response curve of the FceRI is a bell-shaped one showing weak responses at both low and high Ag concentrations (e.g. degranulation and proinflammatory cytokine production) $[27,28]$. Such a curve is reminiscent of the so-called precipitin curves resulting from the titration of Ag against a fixed amount of antiserum in solution (a.k.a. Heidelberger curves) [29]. In such an assay, only an optimal ratio between $\mathrm{Ag}$ and $\mathrm{Ab}$ (called the zone of equivalence) results in the formation of a visible precipitate, whereas both excess $\mathrm{Ab}$ or surplus $\mathrm{Ag}$ prevents formation of a visible precipitate. In the typical laboratory situation, MCs are preloaded with IgE (usually of one specificity, such as anti-dinitrophenyl (DNP) IgE) and then are stimulated with different concentrations of the respective multivalent $\mathrm{Ag}$, such as $\mathrm{DNP}_{30-40}-\mathrm{HSA}$ [27]. Alternatively, cross-linking can be induced by using anti-IgE immunoglobulins. Because of the similarities between the Ag/IgE-induced bell-shaped dose-response curves obtained with MCs and basophils and the in-solution precipitin curves, interpretation of the bell-shaped Ag/IgE-induced dose-response curve was often as sketched in Figure 2. Specifically, a suboptimal dose of multivalent $\mathrm{Ag}$ (i. e. a high $\mathrm{Ab} / \mathrm{Ag}$ ratio) was thought to cross-link only a few IgE-bound FceRIs, resulting in a weak activation of downstream signaling pathways and effector functions (Figure 2A). An optimal Ag concentration, reflecting the zone of equivalence, was thought to optimally cross-link all IgE-bound receptors, thus causing strong activation of Ag-triggered signaling pathways and maximal induction of effector functions (Figure $2 \mathrm{~B}$ ). Increasing the $\mathrm{Ag}$ dose to the socalled supra-optimal concentration range (i. e. a low $\mathrm{Ab} /$ Ag ratio) was then thought to result in the formation of monovalent complexes with every IgE binding "its own" $\mathrm{Ag}$ and thus Ag-mediated cross-links between different IgE-bound FceRIs were lost (Figure 2C). Similar to the sub-optimal situation, only marginal execution of effector functions combined with weak activation of downstream signaling pathways would thus be attained.

\section{The precipitin-type model of FceRI regulation revisited}

In 1973, Becker et al. investigated IgE/FceRI redistribution and histamine release in human basophils in response to increasing concentrations of anti-IgE Abs [30]. They found that histamine release only occurred in the presence of sub-optimal to optimal levels of anti-IgE, whereas IgE/FceRI redistribution was mainly observable at higher, supra-optimal concentrations of cross-linking agent [30]. This interesting finding was re-addressed by Magro and Alexander using a different approach [31]. In their experiments they studied histamine release from leukocytes of ragweed sensitive donors, again using antiIgE Abs to cross-link IgE-bound FceRIs. They were 

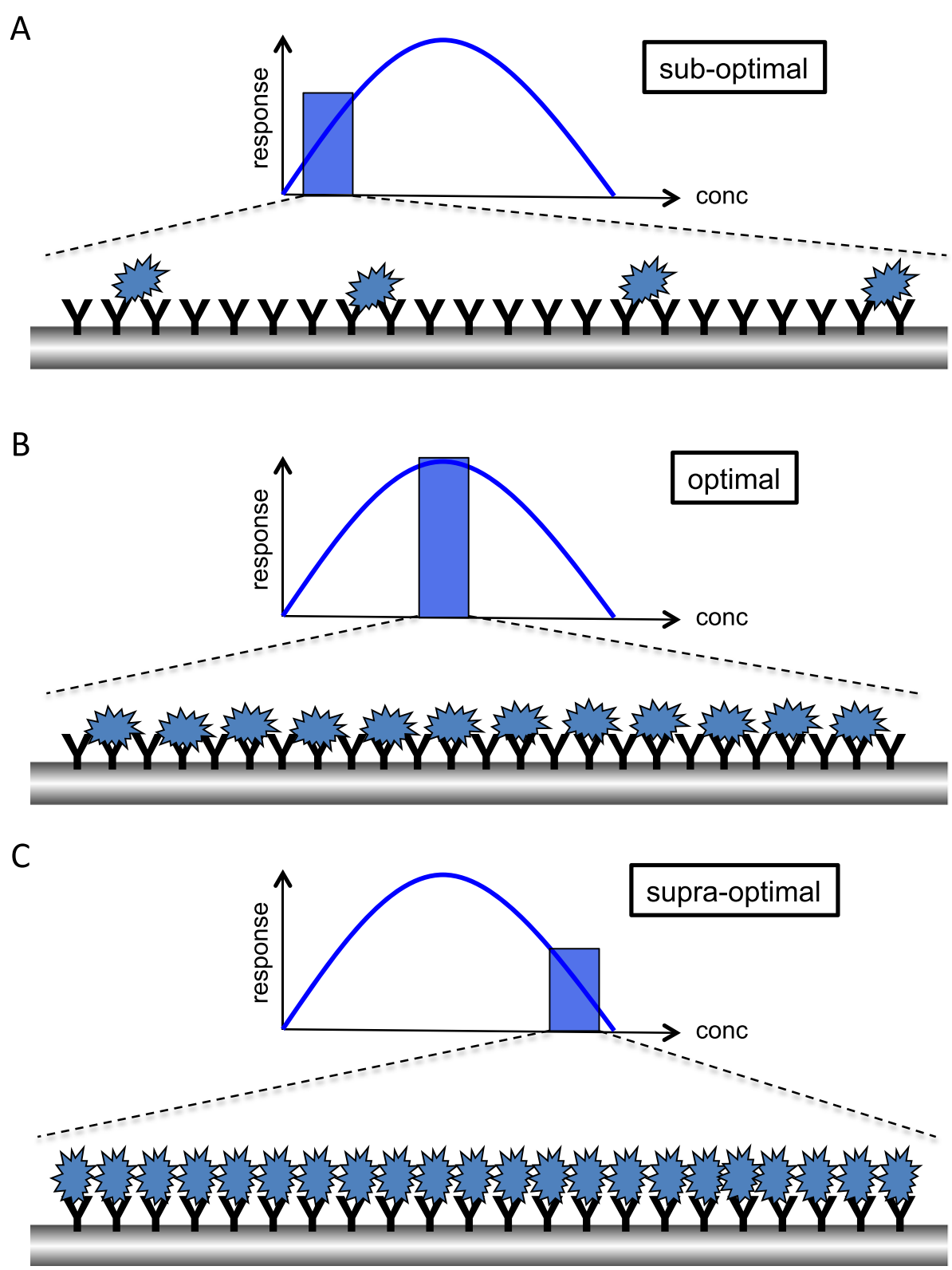

Figure 2 The precipitin-type model-a first attempt to explain Fc\&RI dose-response behavior. (A) A sub-optimal dose of multivalent Ag would only cross-link a minor fraction of IgE-bound FcERls and result in only weak downstream signaling and induction of effector functions. (B) An equivalent Ag concentration optimally would cross-link all IgE-bound receptors and cause maximal activation of Ag-triggered signaling pathways and effector functions. (C) High, supra-optimal concentrations of multivalent Ag were initially thought to result in the formation of monovalent complexes with every lgE binding "its own" Ag. Thus, cross-linking of IgE-bound FceRl should not occur. Comparable to the suboptimal situation only weak signaling and execution of effector functions would be the outcome. Of note, this model of FceRl activation based on the precipitin curve of in-solution immunoprecipitation is not supported by experimental data (see text).

interested in the effects of monomeric Fab fragments of these anti-IgE Abs and found that for a sub-optimal to optimal concentration of anti-IgE increasing concentrations of the monomeric Fab fragments inhibited the release of histamine. This was expected since the monomers reduced receptor cross-linking by the intact anti-IgE Abs. At supra-optimal concentrations of anti-IgE Abs, however, increasing concentrations of the monomer enhanced histamine release. Thus, they concluded that the descending portion of the dose-response curve might be the result of an active turn-off mechanism caused by an excess of bridging rather than the reduced bridging due to monovalent interactions depicted in the model in Figure 2C [31]. Of note, the model shown in Figure 2 was only based on similarity to the Heidelberger curves of in-solution immunoprecipitation and not on experimental data. 
How would secretion of histamine be suppressed when FceRIs are supra-optimally cross-linked? Baird and coworkers reported that stimulation of IgE-bound FceRI by polyclonal Abs against IgE induced a detergentresistant association of these complexes with the cellular cytoskeleton [32]. In thorough dose-response studies, the extent of the cytoskeletal association followed the extent of FceRI bridging and, more importantly, continued to increase beyond the anti-IgE concentration where degranulation was maximal [32]. This strongly indicated that stimulation of MCs with supra-optimal Ag concentrations, that results in little or no degranulation, did cause intracellular rearrangements. A further study by Oliver and colleagues verified that detergentinsolubility of FceRI-IgE-Ag complexes did not correlate with degranulation [33]. Moreover, using inhibitors of actin polymerization, they could increase degranulation at supra-optimal Ag concentrations, while detergentinsolubility was decreased [33]. From these studies they concluded that Ag-triggered actin polymerization is more likely related to the termination/inhibition than to the stimulation of degranulation, in particular at supraoptimal Ag concentrations [33]. This also suggested that stronger actin polymerization was induced by supraoptimal than by optimal doses of Ag. It further indicated that strong activation of signal transduction events, at least those related to actin polymerization, occurred at supra-optimal Ag concentrations. Finally, Seagrave et al. using scanning electron microscopy showed that optimally cross-linked FceRIs redistribute into chains and small clusters, whereas supra-optimally cross-linked receptors redistribute into clusters and large aggregates [34]. Again, large aggregates at high stimulus concentrations were prevented from forming by adding either monovalent ligands or actin depolymerizing agents.

Thus, suppressed degranulation in response to supraoptimal Ag appeared not to be due to reduced FceRI crosslinking, as depicted in Figure $2 \mathrm{C}$. This then begged the question, was the optimal crosslinking of the majority of receptors shown in Figure $2 \mathrm{~B}$ accurate? To partially address this it was demonstrated, using stable oligomers of IgE prepared by chemical crosslinking, that no more than a few hundred trimers or an even smaller number of higher oligomers are required to induce a considerable amount of degranulation from RBL-2H3 MCs [35]. Using monoclonal Abs directed against the $\alpha$ chain of the FceRI, a study by Pecht and colleagues not only demonstrated that FceRI aggregates as small as dimers are capable of providing an effective stimulus for degranulation but that only a small fraction of FceRI needs to be cross-linked in order to yield optimal degranulation [36]. Also, for basophils, MacGlashan showed that only a few hundred FceRI are needed for meaningful secretion to occur [37].

\section{Signal transduction in the supra-optimal world - an inhibitory signalosome?}

All these studies indicated that the bell-shaped doseresponse curve of $\mathrm{MC}$ degranulation might not reflect the level of signaling taking place inside the cells. Thus, it was important to elucidate the signaling pathways controlling $\mathrm{MC}$ activation in response to differing concentrations of Ag. A critical step in regulating IgE-induced degranulation is the release of intracellular $\mathrm{Ca}^{2+}$ ions from the ER with subsequent influx of extracellular $\mathrm{Ca}^{2+}$ via store-operated $\mathrm{Ca}^{2+}$ (SOC) channels $[7,38,39]$. This response was shown to follow the bell-shaped dose-response curve with weak $\mathrm{Ca}^{2+}$ mobilization in response to sub- as well as supraoptimal Ag concentrations and strong responses after optimal cross-linking [27]. Interestingly, $\mathrm{Ca}^{2+}$ mobilization at supra-optimal was not simply weaker than at optimal Ag concentrations, but the sustained pattern (optimal) changed to a transient one (supra-optimal), suggesting active negative regulation. Consistent with this, early overall tyrosine phosphorylation events were slightly enhanced in supra-optimally vs. optimally stimulated MCs [27,40]. Particularly, tyrosine phosphorylation of a $145 \mathrm{kDa}$ protein was increased in parallel to the $\mathrm{Ag}$ levels and this protein was identified as the $\mathrm{SH} 2$-containing inositolpolyphosphate $5^{\prime}$-phosphatase, SHIP1, a critical negative regulator of PI3K signaling $[27,41,42]$. SHIP1 hydrolyzes phosphatidylinositol-3,4,5-trisphosphate ( $\left.\mathrm{PIP}_{3}\right)$, the product of the $\mathrm{PI} 3 \mathrm{~K}$-catalyzed reaction, to yield PI-3,4- $\mathrm{P}_{2}[43,44]$. This indicated that SHIP1 was involved in the regulation of the descending part of the doseresponse curve and, indeed, SHIP1-deficient bone marrow-derived MCs (BMMCs) only showed weak or no reduction of degranulation in response to supra-optimal antigen concentrations. Correlating with this, SHIP1deficient BMMCs, even at supra-optimal conditions, showed sustained $\mathrm{Ca}^{2+}$ mobilization [27].

Related to this, the SFK Lyn has been shown to phosphorylate and activate SHIP1 in MCs and degranulation studies with Lyn-/- BMMCs have revealed that these cells do not display the descending part of the bellshaped degranulation curve [45]. Interestingly, Lyn has also been shown to tyrosine phosphorylate protein kinase $C-\delta(P K C-\delta)$ and complexes of Lyn with SHIP1 and $\mathrm{PKC}-\delta$ have been reported [46-48]. Relevant to this, Leitges et al. observed augmented Ag-triggered degranulation in $\mathrm{PKC}-\delta$-deficient BMMCs, in particular in response to supra-optimal stimulus concentrations [47]. These data strongly suggest the existence of an inhibitory signalosome, which appears to be particularly active when MCs are stimulated by supra-optimal Ag concentrations.

How could one envision the functional coupling between supra-optimally cross-linked FceRIs and such an inhibitory signalosome? Intriguingly, the $\beta$-subunit of 
the FceRI, which has been carefully described by Kinet and colleagues as the amplifier of FceRI-mediated activation signals $[25,49]$, has been found by different laboratories to be most highly tyrosine-phosphorylated in response to high Ag concentrations [27,50,51]. In this respect, in a very elegant and thorough study, Xiao et al. demonstrated that Lyn was most activated under supraoptimal conditions, resulting in pronounced $\beta$-subunit ITAM as well as SHIP1 tyrosine phosphorylation and suppressed degranulation as well as cytokine production [51]. Importantly, there are two differences between the $\beta$-chain and FcRgamma ITAMs, namely the $\beta$-ITAM has a shorter spacer between its two YXXL sequences (six amino acids ( $\beta$ ) vs. seven amino acids (FcRgamma)), and the spacer region of the $\beta$-chain contains an additional tyrosine residue. Thus, the $\beta$-subunit via its unique ITAM may utilize Lyn to negatively regulate downstream events in response to supra-optimal Ag concentrations [51]. This puts the FceRI $\beta$-chain and the SFK Lyn at the center of initiation of suppressive FceRI-mediated signaling and SHIP1, by controlling the PI3K pathway, as one of the important downstream regulators of this response. However, there are certainly more signaling proteins involved in this process, such as PKC- $\delta$ mentioned above [47].

Interestingly, analyzing GPVI-mediated dense granule secretion from platelets, Kunapuli and coworkers found that functional interactions between Lyn, PKC- $\delta$, and SHIP1 negatively regulate this process as well [52]. GPVI is a receptor for collagen on platelets that triggers signaling via an associated FcRgamma [53]. Since no FceRI $\beta$-chain interacts with this receptor complex, the inhibitory signalosome comprising Lyn, PKC- $\delta$, and SHIP1 appears to be capable of acting in a $\beta$-chain ITAMindependent manner. This is intriguing since the unique tyrosine residue between the canonical ITAM tyrosines of the $\beta$-chain has been shown to be very important for interaction with SHIP1 [54]. Nevertheless, this suggests that such an inhibiting/attenuating mechanism can also be functional in cells which only express an FceRI lacking the $\beta$-chain, such as Langerhans and dendritic cells [22].

In MCs, two additional prominent $\mathrm{PIP}_{3}$ phosphatases are expressed that participate in regulation of the PI3K pathway, namely the $5^{\prime}$-phosphatase SHIP2 and the $3^{\prime}$-phosphatase PTEN. SHIP2 has been knocked-down by shRNA in BMMCs and shown to result in stronger FceRI-induced degranulation at every $\mathrm{Ag}$ concentration tested, compared to cells treated with control shRNA [55]. However, the effect was most pronounced at optimal Ag concentrations and only marginal at supraoptimal Ag concentrations. Also, in contrast to SHIP1-deficient cells, there was no effect of SHIP2 reduction on Ag-triggered $\mathrm{Ca}^{2+}$ mobilization [55]. On the other hand, SHIP2 knock-down resulted in enhanced microtubule reorganization, which might explain the observed positive effect on degranulation in the absence of augmented $\mathrm{Ca}^{2+}$ mobilization [56]. These results indicate that SHIP1 is more involved than SHIP2 in repressing supra-optimal Ag-induced degranulation. PTEN, a prominent tumor suppressor, was also knocked-down by an shRNA approach in human MCs and cells with reduced PTEN expression were shown to react with augmented $\mathrm{Ca}^{2+}$ mobilization as well as degranulation in response to FceRI activation [57]. Unfortunately, titration of cross-linking Ag was not extended to the supra-optimal range and thus, no statement can be made at present on PTEN's role in repressing degranulation at very high $\mathrm{Ag}$ concentrations. However, this analysis did show that PTEN (and not SHIP1 nor SHIP2) is crucially involved in the "homeostatic" control of $\mathrm{PIP}_{3}$ levels in unstimulated MCs [57].

How SHIP1 controls degranulation in response to supra-optimal Ag concentrations is not entirely clear at the moment. Because of its structure, SHIP1 incorporates catalytic as well as adaptor functions [58]. Even on the basis of its catalytic activity two mechanisms, not necessarily mutually exclusive, could be responsible. First, by hydrolyzing $\mathrm{PIP}_{3}$, SHIP1 would suppress various $\mathrm{PIP}_{3}$-dependent molecules/pathways, one or more of them critically involved in $\mathrm{Ca}^{2+}$ mobilization and degranulation (e.g. phospholipase C- $\gamma 1$ (PLC- $\gamma 1$ ), PLC- $\gamma 2$, and the tyrosine kinase Btk [7,59]). Second, by hydrolyzing $\mathrm{PIP}_{3}$, PI-3,4- $\mathrm{P}_{2}$ is generated, which is known to specifically interact with $\mathrm{PH}$-domains of certain signaling proteins, e.g. the adaptor proteins Bam32/DAPP1, TAPP1, and TAPP2 [60]. Related to this, Bam32-deficiency has been demonstrated to result in augmented $\mathrm{Ca}^{2+}$ mobilization and degranulation in response to supra-optimal $\mathrm{Ag}$ concentrations, suggesting that Bam32 represents an effector of SHIP1's negative activity [61]. Intriguingly, compared to wild-type BMMCs Bam32-deficient BMMCs show reduced Lyn and SHIP1 phosphorylation in response to $\mathrm{Ag}$, indicating the presence of so far uncharacterized feed-back mechanisms [61].

With respect to SHIP1's adaptor or scaffolding function, increasing numbers of interaction partners of SHIP1 have been and continue to be identified. SHIP1 contains an N-terminal SH2-domain, a centrally located $5^{\prime}$-phosphatase domain, and a C-terminus containing several proline-rich sequences as well as two NPxY motifs [58]. The SH2-domain is capable of binding to the phosphorylated ITAM sequences of the FceRI $\beta$-chain and FcRgamma [62,63]. In keeping with this, additional ITAM sequences have been demonstrated to be bound by the SHIP1 SH2-domain [64-66]. Three of the proline-rich motifs in SHIP1's C-terminus show good consensus for binding to SH3-domains of other 
proteins and several have been experimentally verified, such as Grb2, CIN85, and Src kinase [67-69]. This might suggest that Lyn via its SH3-domain can also interact with SHIP1 in the context of the inhibitory signalosome. Indeed, SHIP1 could be pulled-down from MC lysates by means of a GST-SH3 (Lyn) fusion protein (unpublished data). Recently, a pleckstrin homology-related domain has been identified that is present $\mathrm{N}$-terminal to the $5^{\prime}$-phosphatase domain and shown to mediate membrane localization of SHIP1 by binding to $\mathrm{PIP}_{3}$ [70].

Finally, proteins containing so-called phosphotyrosinebinding (PTB)-domains, such as the adaptor proteins Shc and p62Dok1, have been demonstrated to bind to SHIP1's C-terminal NPxY motifs upon their phosphorylation [71-73]. Since Shc contains both a PTB-domain as well as an SH2-domain, it was thought initially that Shc took SHIP1 to the FceRI. However, analysis of SHIP1deficient BMMCs suggested a different binding order since FceRI-mediated Shc tyrosine phosphorylation was dependent on SHIP1 expression [74]. Thus, Shc might be involved in limiting SHIP1's activity at the receptor by "tearing" it away upon Shc's tyrosine phosphorylation by Lyn. Shc, however, has also been implicated as a linker between SHIP1 and PKC- $\delta$ by binding to SHIP1 via its PTB-domain and to PKC- $\delta$ by means of its SH2-domain [47]. The adaptor protein p62Dok1, a wellknown interaction partner of the GTPase-activating protein RasGAP, has also been shown to bind to SHIP1 and inhibit p21Ras and hence, be a negative regulator of the canonical MAPK pathway (Erk1/2) [72,73]. Interestingly, Erk1/2 might positively regulate FceRI-mediated MC degranulation via two different pathways. Pecht and colleagues have reported that Erk1 is part of a feedforward loop positively controlling Syk activity upon FceRI triggering [75]. Pharmacologic inhibition of the Erk kinase MEK suppressed Ag-induced MC degranulation [75]. This effect was recently corroborated with novel MEK inhibitors with higher selectivity [76]. Another mechanism by which Erk $1 / 2$ could positively regulate $\mathrm{MC}$ degranulation is suggested by an interesting finding by Pozo-Guisado et al. They demonstrated that Erk1/2 can phosphorylate STIM1, an important calcium sensor in the membrane of the endoplasmic reticulum, and thereby positively modulate store-operated calcium entry, which is mandatory for degranulation to occur $[38,77]$. Since the p62Dok1-SHIP1 interaction depends on SHIP1 tyrosine phosphorylation [73] and SHIP1 tyrosine phosphorylation is enhanced upon supra-optimal FceRI triggering [27], Erk1/2 activity could be reduced, contributing to the lack of degranulation under such conditions. Thus, by combining catalytic as well as adaptor functions SHIP1 has the potential to contribute to the regulation of $\mathrm{MC}$ activation under supra-optimal Ag conditions in several ways.
As far as other possible negative regulators of supraoptimal FceRI-induced MC degranulation are concerned, Xiao et al. showed that both SHIP1 and SHP-1 interacted with the FceRI $\beta$-chain and that their phosphorylation was controlled by Lyn [51]. However, studies to date using MCs from different mouse models (motheaten (me) mice [78] and viable motheaten (mev) mice [79]) have not unequivocally confirmed a negative role for SHP-1 with respect to degranulation. Nakata et al. compared BMMCs from wild-type and me mice and measured decreased $\mathrm{Ca}^{2+}$ mobilization and degranulation in me BMMCs in response to Ag [78]. On the other hand, Zhang et al. studied BMMCs from $m e^{v}$ mice, which were found to degranulate in an augmented fashion compared to wild-type BMMCs [79]. The observed differences might be due, in large part, to the diverse effects on protein expression of the different mutations within the gene coding for SHP-1 [80]. Unfortunately, in these SHP-1-related studies, like so many other FceRI-induced studies to date, Ag dose-responses were not extended to the supra-optimal range.

The Cbl family of E3 ubiquitin-protein ligases comprises three mammalian members, c-cbl, Cbl-b, and Cbl-c. These proteins poly-ubiquitinate various cellular proteins, thereby targeting them for proteasomal degradation [81]. Applying overexpression of $\mathrm{c}$-cbl in the RBL-2H3 MC line, Ota and Samelson previously showed that $\mathrm{c}$-cbl is able to negatively affect MC degranulation by inhibiting the tyrosine kinase Syk [82]. However, a comparison of wild-type and c-cbl-deficient BMMCs did not yield differences in Ag-triggered degranulation [83]. On the other hand, the same study revealed significant differences between wild-type and Cbl-b-deficient BMMCs, indicating non-redundant functions of Cbl family members in MCs. In response to Ag, enhanced tyrosine phosphorylation of the FceRI ITAMs, Syk, and PLC- $\gamma 1 / 2$ as well as $\mathrm{Ca}^{2+}$ mobilization was shown in Cbl-b-deficient BMMCs. This resulted in augmented degranulation at every Ag concentration studied with the most prominent effect at high, supra-optimal concentrations [83], suggesting that Cbl-b is involved in the negative control of $\mathrm{MC}$ activation in response to supra-optimal cross-linking. Interestingly, CIN85 (Cbl-interacting protein of $85-\mathrm{kDa}$ ) was shown to interact with Cbl-b and SHIP1, suggesting the presence of an additional SHIP1-containing inhibitory signalosome $([69,84]$ \& unpublished results). Ag stimulation of RBL-2H3 MCs caused co-translocation of Cbl-b, Lyn, and the FceRI into lipid rafts [85]. Overexpression of a lipid raft-anchored form of Cbl-b resulted in severe reduction of Ag-triggered tyrosine phosphorylation of the FceRI ITAMs, Syk, and PLC- $\gamma 1 / 2, \mathrm{Ca}^{2+}$ mobilization, and degranulation [85]. Unexpectedly, degranulation was least affected at high antigen concentrations suggesting differential functions of raft- and non-raft-localized Cbl-b with respect to supra-optimal stimulation. Interestingly, Jnk 
phosphorylation was almost completely inhibited by the lipid raft-anchored form of Cbl-b, whereas other MAPKs (Erk, p38) were not [85], and Jnk1 was suggested recently to be important for MC degranulation [86]. Again, thorough dose-response studies are lacking for a further evaluation of Jnk function in response to supra-optimal Ag stimulation.

\section{FcERI and FcyRIIB (CD32) - brothers in spirit}

Immune complex-induced coaggregation of the FceRI with the inhibitory, low-affinity receptor for IgG, FcyRIIB (CD32), results in suppression of FceRImediated MC activation [87]. In contrast to the FceRI, FcyRIIB is a single-chain receptor containing extracellular IgG-binding immunoglobulin-like domains, a transmembrane region, and an intracellular domain that contains an immunoreceptor tyrosine-based inhibition motif (ITIM). The tyrosine residue within the ITIM is phosphorylated by Lyn, which is activated via FceRI cross-linking [88]. Upon ITIM tyrosine phosphorylation, SHIP1 is able to bind to it by means of its SH2-domain, thus contributing to the down-regulation of PI3Kmediated activation events [89,90]. SHIP1 then gets phosphorylated by Lyn as well and is able to recruit a complex consisting of p62Dok1 and RasGAP, thereby negatively regulating the canonical MAPK pathway [72,73]. Interestingly, two crucial elements of FcyRIIB function, Lyn and SHIP1, are central to the suppression of FceRI signaling at supra-optimal Ag concentrations (this review). Moreover, not only is FceRI function negatively regulated by submembraneous filamentous actin, but also FcyRIIB-dependent negative regulation is dependent on this cytoskeletal component [91]. Given such similarities it is tempting to suggest that one might be able to transfer mechanisms from one system to the other. PKC- $\delta$ could participate in translating Fc $\gamma$ RIIB's negative function and the SHIP1-p62Dok1-RasGAP complex might be involved in supra-optimal FceRI signaling. In fact, inducible interactions of SHIP1, p62Dok1, and RasGAP can be observed in response to FceRI triggering (unpublished data). However, one important difference between SHIP1 binding to FcyRIIB vs. FceRI is that binding of the SHIP1 SH2-domain to the phosphorylated ITIM is of high affinity whereas it is of low affinity to ITAM sequences [66]. Moreover, the FcyRIIB-SHIP1 interaction is stabilized by the small adaptor protein Grb2, which binds to SHIP1 via an $\mathrm{SH} 3$-domain and by means of its $\mathrm{SH} 2$-domain to a second tyrosine-containing motif within the cytoplasmic domain of FcyRIIB [92]. The reason for this difference in affinity may lie with the distinct actions of SHIP1 on FceRI- and FcyRIIB-induced signaling. The task of SHIP1 at the FcyRIIB is to "simply" stop cellular activation, quickly and completely. Since SHIP1 is engaged not only in response to supra-optimal triggering of the FceRI but also during its activation by sub-optimal to optimal Ag concentrations [74], SHIP1's function here is more an attenuating rather than an inhibitory one.

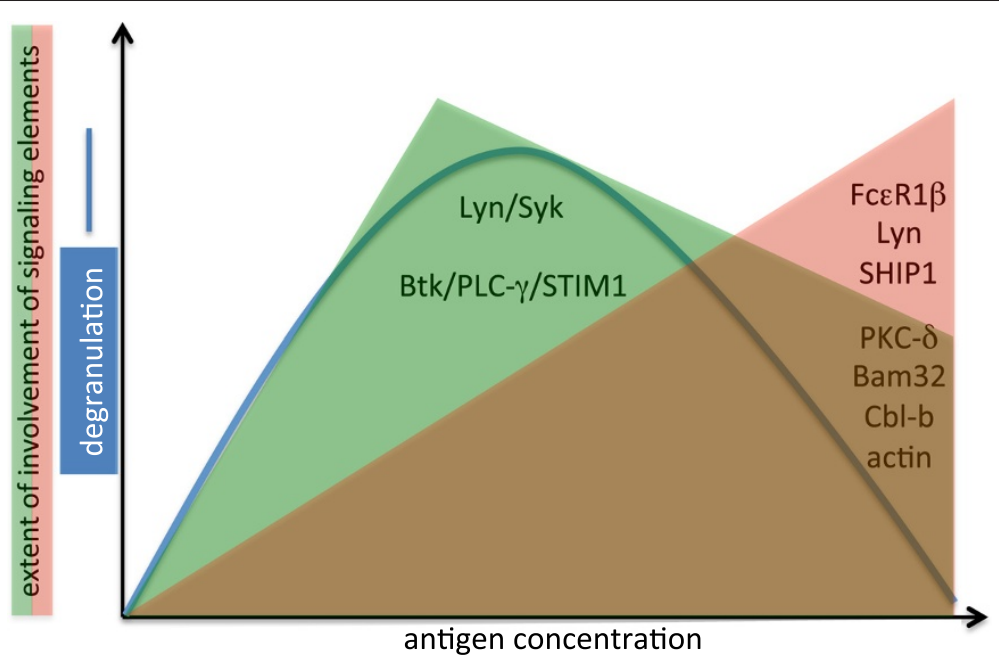

Figure 3 Activating and inhibitory proteins shape the outcome of FcERI stimulation by different Ag concentrations. The Ag-triggered activation of the FceRl generates both positive and negative signals, which are integrated to determine the quantity of the response. At every Ag concentration both types of signals are generated, however, their ratio and composition differs depending on the antigen dose. Low to optimal Ag concentrations preferentially engage activating signaling elements (green area and proteins indicated there; the tyrosine kinases Lyn and Syk act proximal to the receptor; Btk, PLC- $\gamma$, and STIM1 control $\mathrm{Ca}^{2+}$ mobilization). In response to high, supra-optimal Ag concentrations negative signaling elements are increasingly recruited (red triangle and proteins indicated there; FcعRIß, Lyn, and SHIP1 are central to the inhibitory signalosome; PKC- $\delta$, Bam32, Cbl-b, and actin transduce suppressive signals at supra-optimal Ag). Note that the SFK Lyn is both an activating and an attenuating element depending on the Ag dose (see text). 
High-affinity binding and attenuation might be mutually exclusive.

\section{The whole picture (?)}

Without a doubt the field has come a long way since the precipitin-type model of supra-optimal FceRI activation. As stated in this review, several proteins can be assigned inhibitory functions in response to supra-optimal $\mathrm{Ag}$ concentrations (Figure 3). However, one can assume that there are more regulatory proteins to be discovered. To accomplish the bell-shaped dose-response curve of FceRI-mediated MC activation, both positive and negative signals have to be generated and integrated to determine the quantity as well as the quality of the response. Thus, altered positive signaling might result in stronger attenuation at high $\mathrm{Ag}$ concentrations. This was shown comparing Ag-triggered histamine release in wild-type, Lyn-deficient, and Btk-deficient BMMCs. Whereas Lyn-deficient BMMCs showed no reduction of degranulation at high $\mathrm{Ag}$ concentrations, compared to wild-type cells, Btk-deficient BMMCs exerted stronger attenuation than wild-type BMMCs [93], consistent with the accepted positive regulatory role for Btk in FceRI signaling [94]. A further interesting point is the differential dose-response behavior of Ag-triggered MCs with respect to different pro-inflammatory effector functions. Both immediate degranulation and subsequent production of pro-inflammatory cytokines (e.g. IL-6 and TNF-alpha follow a bell shape. However, the descending part of the curve is significantly steeper concerning cytokine production [27,28,95]. Moreover, Rivera and coworkers elegantly demonstrated that Ag-induced mediators, such as various cytokines and chemokines, needed different $\mathrm{Ag}$ concentrations for their optimal expression [96]. This strongly suggests that there is not one activating and one inhibitory signal, but for different $\mathrm{MC}$ responses there might be specially balanced signaling pathways or networks.

\section{Conclusions}

The bell-shaped dose-response behavior represents a remarkable feature of the FceRI. Nature provides us with an efficient shut-off mechanism at high, supra-optimal Ag concentrations, which could be employed to alleviate allergic symptoms. By deciphering the molecular language of inhibitory signaling in response to supraoptimal $\mathrm{Ag}$ concentrations one might identify novel targets for pharmacologic therapeutic interventions to benefit patients with acute and chronic allergic diseases. A deeper understanding of this mechanism(s) should also help to elucidate the molecular events that occur during hyposensitization of allergy patients. Finally, the bell-shaped dose response pattern is not unique to the FceRI, but can also be found with other receptors that signal in an ITAM-dependent manner, such as the FcyRIII (CD16) and the B cell antigen receptor [97,98]. Thus, improving our understanding of the regulation of FceRI signaling will also enhance our understanding of other immunologically important receptors.

\section{Competing interests}

The author declares that he has no competing interests.

\section{Acknowledgements}

The author cordially thanks Dr. Gerry Krystal for critical reading of the manuscript and suggestions. Members of the Huber Laboratory are acknowledged for discussions of the subject.

This work was supported by a grant from the Deutsche

Forschungsgemeinschaft (DFG HU794/5-1).

Received: 4 September 2012 Accepted: 13 January 2013

Published: 22 January 2013

\section{References}

1. Metz M, Maurer M: Mast cells-key effector cells in immune responses. Trends Immunol 2007, 28(5):234-241.

2. Echtenacher B, Mannel DN, Hultner L: Critical protective role of mast cells in a model of acute septic peritonitis. Nature 1996, 381(6577):75-77.

3. Malaviya R, Ikeda T, Ross E, Abraham SN: Mast cell modulation of neutrophil influx and bacterial clearance at sites of infection through TNF-alpha. Nature 1996, 381(6577):77-80.

4. Pennock JL, Grencis RK: The mast cell and gut nematodes: damage and defence. Chem Immunol Allergy 2006, 90:128-140.

5. Wang Z, Lai Y, Bernard JJ, Macleod DT, Cogen AL, Moss B, Di Nardo A: Skin mast cells protect mice against vaccinia virus by triggering mast cell receptor S1PR2 and releasing antimicrobial peptides. J Immunol 2012, 188(1):345-357.

6. Galli SJ, Tsai M, Piliponsky AM: The development of allergic inflammation. Nature 2008, 454(7203):445-454.

7. Turner $\mathrm{H}$, Kinet JP: Signalling through the high-affinity lgE receptor FceR1. Nature 1999, 402:B24-B30.

8. Costa JJ, Weller PF, Galli SJ: The cells of the allergic response: mast cells, basophils, and eosinophils. JAMA 1997, 278(22):1815-1822.

9. Feyerabend TB, Weiser A, Tietz A, Stassen M, Harris N, Kopf M, Radermacher P, Moller P, Benoist C, Mathis D, et al: Cre-mediated cell ablation contests mast cell contribution in models of antibody- and T cell-mediated autoimmunity. Immunity 2011, 35(5):832-844.

10. Blank U, Ra C, Miller L, White K, Metzger H, Kinet JP: Complete structure and expression in transfected cells of high affinity lgE receptor. Nature 1989, 337(6203):187-189

11. Garman SC, Kinet JP, Jardetzky TS: Crystal structure of the human high-affinity lgE receptor. Cell 1998, 95(7):951-961.

12. Reth M: Antigen receptor tail clue. Nature 1989, 338(6214):383-384.

13. Yamashita T, Mao SY, Metzger H: Aggregation of the high-affinity lgE receptor and enhanced activity of p53/56lyn protein-tyrosine kinase. Proc Natl Acad Sci USA 1994, 91(23):11251-11255.

14. Vonakis BM, Chen $\mathrm{H}$, Haleem-Smith $\mathrm{H}$, Metzger $\mathrm{H}$ : The unique domain as the site on Lyn kinase for its constitutive association with the high affinity receptor for IgE. J Biol Chem 1997, 272(38):24072-24080.

15. Ravetch JV, Kinet JP: Fc receptors. Annu Rev Immunol 1991, 9:457-492.

16. Garman SC, Wurzburg BA, Tarchevskaya SS, Kinet JP, Jardetzky TS: Structure of the Fc fragment of human IgE bound to its high-affinity receptor Fc epsilonRI alpha. Nature 2000, 406(6793):259-266.

17. Asai K, Kitaura J, Kawakami Y, Yamagata N, Tsai M, Carbone DP, Liu FT, Gall SJ, Kawakami T: Regulation of mast cell survival by IgE. Immunity 2001, 14(6):791-800.

18. Kalesnikoff J, Huber M, Lam V, Damen JE, Zhang J, Siraganian RP, Krystal G: Monomeric IgE stimulates signaling pathways in mast cells that lead to cytokine production and cell survival. Immunity 2001, 14(6):801-811.

19. Yamaguchi M, Lantz CS, Oettgen HC, Katona IM, Fleming T, Miyajima I, Kinet JP, Galli SJ: IgE enhances mouse mast cell Fc(epsilon)Rl expression in vitro and in vivo: evidence for a novel amplification mechanism in IgE-dependent reactions. J Exp Med 1997, 185(4):663-672. 
20. de Andres B, Rakasz E, Hagen M, McCormik ML, Mueller AL, Elliot D, Metwali A, Sandor M, Britigan BE, Weinstock JV, et al: Lack of Fc-epsilon receptors on murine eosinophils: implications for the functional significance of elevated IgE and eosinophils in parasitic infections. Blood 1997, 89(10): 3826-3836.

21. Gounni AS, Lamkhioued B, Ochiai K, Tanaka Y, Delaporte E, Capron A, Kinet $J P$, Capron M: High-affinity lgE receptor on eosinophils is involved in defence against parasites. Nature 1994, 367(6459):183-186.

22. Bieber T, de la Salle H, Wollenberg A, Hakimi J, Chizzonite R, Ring J, Hanau D, de la Salle C: Human epidermal Langerhans cells express the high affinity receptor for immunoglobulin E (Fc epsilon RI). J Exp Med 1992, 175(5):1285-1290

23. Maurer D, Fiebiger E, Reininger B, Wolff-Winiski B, Jouvin MH, Kilgus O, Kinet $J P$, Stingl G: Expression of functional high affinity immunoglobulin $E$ receptors (Fc epsilon $\mathrm{RI}$ ) on monocytes of atopic individuals. J Exp Med 1994, 179(2):745-750.

24. Donnadieu $\mathrm{E}$, Jouvin $\mathrm{MH}$, Kinet JP: A second amplifier function for the allergy-associated Fc(epsilon)RI-beta subunit. Immunity 2000, 12(5):515-523.

25. Dombrowicz D, Lin S, Flamand V, Brini AT, Koller BH, Kinet JP: Allergy-associated FcRbeta is a molecular amplifier of lgE- and lgGmediated in vivo responses. Immunity 1998, 8(4):517-529.

26. Ullrich A, Schlessinger J: Signal transduction by receptors with tyrosine kinase activity. Cell 1990, 61(2):203-212.

27. Gimborn K, Lessmann E, Kuppig S, Krystal G, Huber M: SHIP down-regulates FcepsilonR1-induced degranulation at supraoptimal lgE or antigen levels. J Immunol 2005, 174(1):507-516.

28. Fehrenbach K, Lessmann E, Zorn CN, Kuhny M, Grochowy G, Krystal G, Leitges M, Huber M: Steel factor enhances supraoptimal antigen-induced IL-6 production from mast cells via activation of protein kinase C-beta. $\mathrm{J}$ Immunol 2009, 182(12):7897-7905

29. Heidelberger M, Kendall FE: A Quantitative Theory of the Precipitin Reaction: lii. The Reaction between Crystalline Egg Albumin and Its Homologous Antibody. J Exp Med 1935, 62(5):697-720.

30. Becker KE, Ishizaka T, Metzger H, Ishizaka K, Grimley PM: Surface IgE on human basophils during histamine release. J Exp Med 1973, 138(2):394-409.

31. Magro AM, Alexander A: Histamine release: in vitro studies of the inhibitory region of the dose-response curve. J Immunol 1974, 112(5):1762-1765

32. Robertson D, Holowka D, Baird B: Cross-linking of immunoglobulin E-receptor complexes induces their interaction with the cytoskeleton of rat basophilic leukemia cells. J Immuno/ 1986, 136(12):4565-4572.

33. Seagrave J, Oliver JM: Antigen-dependent transition of lgE to a detergent-insoluble form is associated with reduced lgE receptordependent secretion from RBL-2H3 mast cells. J Cell Physiol 1990, 144(1):128-136.

34. Seagrave J, Pfeiffer JR, Wofsy C, Oliver JM: Relationship of IgE receptor topography to secretion in RBL-2H3 mast cells. J Cell Physiol 1991, 148(1):139-151.

35. Fewtrell $\mathrm{C}$, Metzger $\mathrm{H}$ : Larger oligomers of lgE are more effective than dimers in stimulating rat basophilic leukemia cells. J Immunol 1980, 125(2):701-710.

36. Ortega E, Schweitzer-Stenner R, Pecht I: Possible orientational constraints determine secretory signals induced by aggregation of $\lg E$ receptors on mast cells. EMBO J 1988, 7(13):4101-4109.

37. MacGlashan DW Jr: Releasability of human basophils: cellular sensitivity and maximal histamine release are independent variables. J Allergy Clin Immunol 1993, 91(2):605-615.

38. Baba Y, Nishida K, Fujii Y, Hirano T, Hikida M, Kurosaki T: Essential function for the calcium sensor STIM1 in mast cell activation and anaphylactic responses. Nat Immunol 2008, 9(1):81-88.

39. Ma HT, Beaven MA: Regulators of $\mathrm{Ca}(2+)$ signaling in mast cells: potential targets for treatment of mast cell-related diseases? Adv Exp Med Biol 2011, 716:62-90

40. Kepley CL, Wilson BS, Oliver JM: Identification of the Fc epsilonRI-activated tyrosine kinases Lyn, Syk, and Zap-70 in human basophils. J Allergy Clin Immunol 1998, 102(2):304-315.

41. Huber M, Kalesnikoff J, Reth M, Krystal G: The role of SHIP in mast cell degranulation and IgE-induced mast cell survival. Immunol Lett 2002, 82(1-2):17-21
42. Krystal G, Damen JE, Helgason CD, Huber M, Hughes MR, Kalesnikoff J, Lam V, Rosten P, Ware RD, Yew S, et al: SHIPs ahoy. Int J Biochem Cell Biol 1999 31(10):1007-1010.

43. Huber M, Helgason CD, Damen JE, Scheid MP, Duronio V, Lam V, Humphries RK, Krystal G: The role of the SRC homology 2-containing inositol 5'-phosphatase in Fc epsilon R1-induced signaling. Curr Top Microbiol Immunol 1999, 244:29-41.

44. Damen JE, Liu L, Rosten P, Humphries RK, Jefferson AB, Majerus PW, Krystal $\mathrm{G}$ : The 145-kDa protein induced to associate with Shc by multiple cytokines is an inositol tetraphosphate and phosphatidylinositol 3,4,5-triphosphate 5-phosphatase. Proc Natl Acad Sci USA 1996, 93(4):1689-1693.

45. Hernandez-Hansen V, Smith AJ, Surviladze Z, Chigaev A, Mazel T, Kalesnikoff J, Lowell CA, Krystal G, Sklar LA, Wilson BS, et al: Dysregulated FcepsilonRI signaling and altered Fyn and SHIP activities in Lyn-deficient mast cells. J Immunol 2004, 173(1):100-112.

46. Grochowy G, Hermiston ML, Kuhny M, Weiss A, Huber M: Requirement for CD45 in fine-tuning mast cell responses mediated by different ligandreceptor systems. Cell Signal 2009, 21(8):1277-1286.

47. Leitges M, Gimborn K, Elis W, Kalesnikoff J, Hughes MR, Krystal G, Huber M: Protein kinase C-delta is a negative regulator of antigen-induced mast cell degranulation. Mol Cell Biol 2002, 22(12):3970-3980.

48. Song JS, Swann PG, Szallasi Z, Blank U, Blumberg PM, Rivera J: Tyrosine phosphorylation-dependent and -independent associations of protein kinase C-delta with Src family kinases in the RBL-2H3 mast cell line: regulation of Src family kinase activity by protein kinase C-delta. Oncogene 1998, 16(26):3357-3368.

49. Lin S, Cicala C, Scharenberg AM, Kinet JP: The Fc(epsilon)Rlbeta subunit functions as an amplifier of Fc(epsilon)Rlgamma-mediated cell activation signals. Cell 1996, 85(7):985-995.

50. Draberova L, Lebduska P, Halova II, Tolar P, Stokrova J, Tolarova H, Korb J, Draber P: Signaling assemblies formed in mast cells activated via Fcepsilon receptor I dimers. Eur J Immunol 2004, 34(8):2209-2219.

51. Xiao W, Nishimoto $H$, Hong H, Kitaura J, Nunomura S, Maeda-Yamamoto M, Kawakami Y, Lowell CA, Ra C, Kawakami T: Positive and negative regulation of mast cell activation by Lyn via the FcepsilonRI. J Immunol 2005, 175(10):6885-6892

52. Chari R, Kim S, Murugappan S, Sanjay A, Daniel JL, Kunapuli SP: Lyn, PKC-delta, SHIP-1 interactions regulate GPVI-mediated platelet-dense granule secretion. Blood 2009, 114(14):3056-3063.

53. Nieswandt B, Bergmeier W, Schulte V, Rackebrandt K, Gessner JE, Zirngibl H: Expression and function of the mouse collagen receptor glycoprotein VI is strictly dependent on its association with the FcRgamma chain. J Biol Chem 2000, 275(31):23998-24002

54. Furumoto Y, Nunomura S, Terada T, Rivera J, Ra C: The FcepsilonRlbeta immunoreceptor tyrosine-based activation motif exerts inhibitory control on MAPK and IkappaB kinase phosphorylation and mast cell cytokine production. J Biol Chem 2004, 279(47):49177-49187.

55. Leung WH, Bolland S: The inositol $5^{\prime}$-phosphatase SHIP-2 negatively regulates IgE-induced mast cell degranulation and cytokine production. $\mathrm{J}$ Immunol 2007, 179(1):95-102.

56. Nishida K, Yamasaki S, Ito Y, Kabu K, Hattori K, Tezuka T, Nishizumi H, Kitamura D, Goitsuka R, Geha RS, et al: Fc\{epsilon\}RI-mediated mast cell degranulation requires calcium-independent microtubule-dependent translocation of granules to the plasma membrane. J Cell Biol 2005, 170(1):115-126.

57. Furumoto Y, Brooks S, Olivera A, Takagi Y, Miyagishi M, Taira K, Casellas R, Beaven MA, Gilfillan AM, Rivera J: Cutting Edge: lentiviral short hairpin RNA silencing of PTEN in human mast cells reveals constitutive signals that promote cytokine secretion and cell survival. J Immunol 2006, 176(9):5167-5171.

58. Rohrschneider LR, Fuller JF, Wolf I, Liu Y, Lucas DM: Structure, function, and biology of SHIP proteins. Genes Dev 2000, 14(5):505-520.

59. Bolland S, Pearse RN, Kurosaki T, Ravetch JV: SHIP modulates immune receptor responses by regulating membrane association of Btk. Immunity 1998, 8(4):509-516.

60. Marshall AJ, Krahn AK, Ma K, Duronio V, Hou S: TAPP1 and TAPP2 are targets of phosphatidylinositol 3-kinase signaling in B cells: sustained plasma membrane recruitment triggered by the B-cell antigen receptor. Mol Cell Biol 2002, 22(15):5479-5491. 
61. Hou S, Pauls SD, Liu P, Marshall AJ: The PH domain adaptor protein Bam32/DAPP1 functions in mast cells to restrain FcvarepsilonRI-induced calcium flux and granule release. Mol Immunol 2010, 48(1-3):89-97.

62. Kimura T, Sakamoto H, Appella E, Siraganian RP: The negative signaling molecule $\mathrm{SH} 2$ domain-containing inositol-polyphosphate 5-phosphatase (SHIP) binds to the tyrosine-phosphorylated beta subunit of the high affinity lgE receptor. J Biol Chem 1997, 272(21):13991-13996.

63. Osborne MA, Zenner G, Lubinus M, Zhang X, Songyang Z, Cantley LC, Majerus P, Burn P, Kochan JP: The inositol 5'-phosphatase SHIP binds to immunoreceptor signaling motifs and responds to high affinity $\lg \mathrm{E}$ receptor aggregation. J Biol Chem 1996, 271(46):29271-29278.

64. Pesesse X, Backers K, Moreau C, Zhang J, Blero D, Paternotte N, Erneux C. SHIP1/2 interaction with tyrosine phosphorylated peptides mimicking an immunoreceptor signalling motif. Adv Enzyme Regul 2006, 46:142-153.

65. Nakamura K, Malykhin A, Coggeshall KM: The Src homology 2 domaincontaining inositol 5-phosphatase negatively regulates Fcgamma receptor-mediated phagocytosis through immunoreceptor tyrosinebased activation motif-bearing phagocytic receptors. Blood 2002, 100(9):3374-3382

66. Mukherjee $O$, Weingarten L, Padberg I, Pracht C, Sinha R, Hochdorfer T, Kuppig S, Backofen R, Reth M, Huber M: The SH2-domain of SHIP1 interacts with the SHIP1 C-terminus: impact on SHIP1/lg-alpha interaction. Biochim Biophys Acta 2012, 1823(2):206-214.

67. Wisniewski D, Strife A, Swendeman S, Erdjument-Bromage H, Geromanos S, Kavanaugh WM, Tempst P, Clarkson B: A novel SH2-containing phosphatidylinositol 3,4,5-trisphosphate 5-phosphatase (SHIP2) is constitutively tyrosine phosphorylated and associated with src homologous and collagen gene (SHC) in chronic myelogenous leukemia progenitor cells. Blood 1999, 93(8):2707-2720

68. Kalesnikoff J, Sly LM, Hughes MR, Buchse T, Rauh MJ, Cao LP, Lam V, Mui A, Huber M, Krystal G: The role of SHIP in cytokine-induced signaling. Rev Physiol Biochem Pharmacol 2003, 149:87-103.

69. Buchse T, Horras N, Lenfert E, Krystal G, Korbel S, Schumann M, Krause E, Mikkat S, Tiedge M: CIN85 interacting proteins in B cells-specific role for SHIP-1. Mol Cell Proteomics 2011, 10(10):M110 006239.

70. Ming-Lum A, Shojania S, So E, McCarrell E, Shaw E, Vu D, Wang I, Mclntosh $L P$, Mui AL: A pleckstrin homology-related domain in SHIP1 mediates membrane localization during Fcgamma receptor-induced phagocytosis. FASEB J 2012, 26(8):3163-3177.

71. Lamkin TD, Walk SF, Liu L, Damen JE, Krystal G, Ravichandran KS: Shc interaction with Src homology 2 domain containing inositol phosphatase (SHIP) in vivo requires the Shc-phosphotyrosine binding domain and two specific phosphotyrosines on SHIP. J Biol Chem 1997 272(16):10396-10401

72. Ott VL, Tamir I, Niki M, Pandolfi PP, Cambier JC: Downstream of kinase, p62 (dok), is a mediator of Fc gamma IIB inhibition of Fc epsilon RI signaling. $\mathrm{J}$ Immunol 2002, 168(9):4430-4439.

73. Tamir I, Stolpa JC, Helgason CD, Nakamura K, Bruhns P, Daeron M, Cambier $J C$ : The RasGAP-binding protein p62dok is a mediator of inhibitory FcgammaRIIB signals in B cells. Immunity 2000, 12(3):347-358.

74. Huber M, Helgason CD, Damen JE, Liu L, Humphries RK, Krystal G: The Src Homology 2-Containing Inositol Phosphatase (Ship) Is the Gatekeeper of Mast Cell Degranulation. Proc Natl Acad Sci USA 1998, 95(19):11330-11335.

75. Xu R, Seger R, Pecht I: Cutting edge: extracellular signal-regulated kinase activates syk: a new potential feedback regulation of Fc epsilon receptor signaling. J Immunol 1999, 163(3):1110-1114.

76. Marschall JS, Wilhelm T, Schuh W, Huber M: MEK/Erk-based negative feedback mechanism involved in control of Steel Factor-triggered production of Kruppel-like factor 2 in mast cells. Cell Signal 2012, 24(4):879-888

77. Pozo-Guisado E, Campbell DG, Deak M, Alvarez-Barrientos A, Morrice NA, Alvarez IS, Alessi DR, Martin-Romero FJ: Phosphorylation of STIM1 at ERK1/ 2 target sites modulates store-operated calcium entry. J Cell Sci 2010, 123(Pt 18):3084-3093.

78. Nakata K, Yoshimaru T, Suzuki Y, Inoue T, Ra C, Yakura H, Mizuno K: Positive and negative regulation of high affinity lgE receptor signaling by Src homology region 2 domain-containing phosphatase 1. J Immunol 2008, 181(8):5414-5424.

79. Zhang L, Oh SY, Wu X, Oh MH, Wu F, Schroeder JT, Takemoto CM, Zheng T, Zhu Z: SHP-1 deficient mast cells are hyperresponsive to stimulation and critical in initiating allergic inflammation in the lung. J Immunol 2010, 184(3):1180-1190
80. Tsui HW, Siminovitch KA, de Souza L, Tsui FW: Motheaten and viable motheaten mice have mutations in the haematopoietic cell phosphatase gene. Nature genet 1993, 4(2):124-129.

81. Rao N, Dodge I, Band H: The Cbl family of ubiquitin ligases: critical negative regulators of tyrosine kinase signaling in the immune system. J Leukoc Biol 2002, 71(5):753-763.

82. Ota Y, Samelson LE: The product of the proto-oncogene c-cbl: a negative regulator of the Syk tyrosine kinase. Science 1997, 276(5311):418-420.

83. Zhang J, Chiang YJ, Hodes RJ, Siraganian RP: Inactivation of c-Cbl or Cbl-b differentially affects signaling from the high affinity lgE receptor. $\mathrm{J}$ Immunol 2004, 173(3):1811-1818.

84. Szymkiewicz I, Kowanetz K, Soubeyran P, Dinarina A, Lipkowitz S, Dikic I: CIN85 participates in Cbl-b-mediated down-regulation of receptor tyrosine kinases. J Biol Chem 2002, 277(42):39666-39672.

85. Qu X, Sada K, Kyo S, Maeno K, Miah SM, Yamamura H: Negative regulation of FcepsilonRI-mediated mast cell activation by a ubiquitin-protein ligase Cbl-b. Blood 2004, 103(5):1779-1786.

86. Guma M, Kashiwakura J, Crain B, Kawakami Y, Beutler B, Firestein GS, Kawakami T, Karin M, Corr M: JNK1 controls mast cell degranulation and IL-1 \{beta\} production in inflammatory arthritis. Proc Natl Acad Sci U S A 2010, 107(51):22122-22127.

87. Daeron M, Malbec O, Latour S, Arock M, Fridman WH: Regulation of highaffinity lgE receptor-mediated mast cell activation by murine low-affinity IgG receptors. J Clin Invest 1995, 95(2):577-585.

88. Malbec O, Fong DC, Turner M, Tybulewicz VL, Cambier JC, Fridman WH, Daeron M: Fc epsilon receptor I-associated lyn-dependent phosphorylation of FC gamma receptor IIB during negative regulation of mast cell activation. J Immunol 1998, 160(4):1647-1658.

89. Ono M, Bolland S, Tempst P, Ravetch JV: Role of the inositol phosphatase SHIP in negative regulation of the immune system by the receptor Fc (gamma)RIIB. Nature 1996, 383(6597):263-266.

90. Fong DC, Malbec O, Arock M, Cambier JC, Fridman WH, Daeron M: Selective in vivo recruitment of the phosphatidylinositol phosphatase SHIP by phosphorylated Fc gammaRIIB during negative regulation of $\lg \mathrm{E}-$ dependent mouse mast cell activation. Immunol Lett 1996, 54(2-3):83-91.

91. Lesourne R, Fridman WH, Daeron M: Dynamic interactions of Fc gamma receptor IIB with filamin-bound SHIP1 amplify filamentous actindependent negative regulation of Fc epsilon receptor I signaling. J Immunol 2005, 174(3):1365-1373.

92. Isnardi I, Lesourne R, Bruhns P, Fridman WH, Cambier JC, Daeron M: Two distinct tyrosine-based motifs enable the inhibitory receptor FcgammaRIIB to cooperatively recruit the inositol phosphatases SHIP1/2 and the adapters Grb2/Grap. J Biol Chem 2004, 279(50):51931-51938.

93. Kawakami Y, Kitaura J, Satterthwaite AB, Kato RM, Asai K, Hartman SE, Maeda-Yamamoto M, Lowell CA, Rawlings DJ, Witte ON, et al: Redundant and opposing functions of two tyrosine kinases, Btk and Lyn, in mast cell activation. J Immunol 2000, 165(3):1210-1219.

94. Hata D, Kawakami Y, Inagaki N, Lantz CS, Kitamura T, Khan WN, MaedaYamamoto M, Miura T, Han W, Hartman SE, et al: Involvement of Bruton's tyrosine kinase in FcepsilonRI-dependent mast cell degranulation and cytokine production. J Exp Med 1998, 187(8):1235-1247.

95. Ra C, Nunomura S, Okayama Y: Fine-tuning of mast cell activation by FcepsilonRlbeta chain. Front Immunol 2012, 3:112.

96. Gonzalez-Espinosa C, Odom S, Olivera A, Hobson JP, Martinez ME, OliveiraDos-Santos A, Barra L, Spiegel S, Penninger JM, Rivera J: Preferential signaling and induction of allergy-promoting lymphokines upon weak stimulation of the high affinity lgE receptor on mast cells. J Exp Med 2003, 197(11):1453-1465.

97. Hazenbos WL, Gessner JE, Hofhuis FM, Kuipers H, Meyer D, Heijnen IA Schmidt RE, Sandor M, Capel PJ, Daeron M, et al: Impaired IgG-dependent anaphylaxis and Arthus reaction in Fc gamma RIII (CD16) deficient mice. Immunity 1996, 5(2):181-188.

98. Campbell KA, Lees A, Finkelman FD, Conrad DH: Co-crosslinking Fc epsilon RII/CD23 and B cell surface immunoglobulin modulates B cell activation. Eur J Immunol 1992, 22(8):2107-2112.

doi:10.1186/1478-811X-11-7

Cite this article as: Huber: Activation/Inhibition of mast cells by supra-optimal antigen concentrations. Cell Communication and Signaling $201311: 7$ 